JINOTEP Vol 8 (1) (2021): 207-215

DOI: $10.17977 /$ um031v8i32021p207

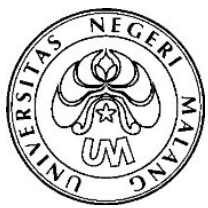

JINOTEP (Jurnal Inovasi Teknologi Pembelajaran)

Kajian dan Riset Dalam Teknologi Pembelajaran

http://journal2.um.ac.id/index.php/jinotep/index

\title{
SCHOOLOGY-BASED E-LEARNING: JUDGING FROM THE QUALITY OF LEARNING
}

\author{
Hana Permata Heldisari ${ }^{1}$, Aldhila Mifta Firdhani ${ }^{2}$
}

${ }^{1}$ Institut Seni Indonesia Yogyakarta, ${ }^{2}$ Universitas Negeri Jakarta

\section{Article History}

Received: 21-06-2021

Accepted: 02-10-2021

Published: 01-11-2021

\section{Keywords}

E-learning, Schoology, Quality of learning.

\begin{abstract}
Abstrak
Penelitian ini bertujuan untuk mendeskripsikan implementasi proses e-learning berbasis Schoology ditinjau dari kualitas pembelajaran. Penelitian ini menggunakan pendekatan kualitatif dengan analisis deskriptif. Hasil penelitian menyatakan bahwa e-learning berbasis Schoology dapat menghasilkan pembelajaran yang berkualitas, yaitu: 1) kemampuan komunikasi melalui tulisan yang lebih baik, baik bagi siswa maupun guru; 2) siswa menjadi lebih aktif karena memiliki kewajiban untuk mengemukakan pendapatnya dalam forum diskusi; 3) setiap individu mampu menciptakan suasana kelas secara mandiri, namun guru tetap memiliki peran untuk menentukan strategi pembelajaran yang tepat agar siswa tidak cepat merasa bosan; 4) Materi pembelajaran lebih terfokus karena minim gangguan dibandingkan proses pembelajaran tatap muka. Selain itu, penggunaan e-learning berbasis schoology memotivasi siswa untuk memiliki target nilai sehingga menjadi lebih serius dalam mengerjakan tugasnya, lebih disiplin baik dalam kehadiran maupun pengumpulan tugas.
\end{abstract}

\begin{abstract}
This study aims to describe the implementation of the Schoology-based e-learning process in terms of learning quality. This study uses a qualitative approach with descriptive analysis. The results of the study stated that Schoology-based e-learning can produce quality learning, namely: 1) better communication skills through writing, both for students and teachers; 2) students become more active because they have an obligation to express their opinions in discussion forums; 3) each individual is able to create a class atmosphere independently, but the teacher still has a role to determine the right learning strategy so that students do not get bored quickly; 4) Learning materials are more focused because there are minimal distractions compared to the face-to-face learning process. In addition, the use of Schoology-based e-learning motivates students to have target values so that they become more serious in doing their assignments, more disciplined both in attendance and in collecting assignments.
\end{abstract}

\footnotetext{
Corresponding author:

Adress: Sombangan RT 3 Kel Sumbersari Kec. Moyudan

Kab. Sleman Daerah Istimewa Yogyakarta Kode Pos 55281

E-mail: hanapermataheldisari@gmail.com
}

2021 Universitas Negeri Malang p-ISSN 2406-8780 e-ISSN 2654-7953 


\section{INTRODUCTION}

As technology grows rapidly, the development of education in formal institutions is increasingly changing and encouraging various efforts to improve the quality of education. The form of information technology development that can be used in learning is by using e-learning. E-learning has a positive impact on the learning process. Teachers need a revolution of learning technologies such as elearning to improve the effectiveness and efficiency of schools' teaching and learning processes (Rahmadoni et al., 2020). E-learning can also increase students' learning motivation which can have an impact on learning outcomes (Tambunan et al., 2018). E-learning can be seen as a system developed in an effort to improve the quality of learning that can overcome space and time limitations, especially during the current Covid-19 pandemic. E-learning gives hope as an alternative solution to most of Indonesia's educational problems, with the function of that can be adjusted to the needs, both as supplements (supplements), complements (complements), or substitution (substitute) for learning activities in the classroom that have been used (Choirudin, 2017).

In e-Learning, two-way communication systems can be categorized into two, namely synchronous and asynchronous. Synchronous means the learning process occurs simultaneously, allowing direct interaction between educators and students online. It describes an offline class but is virtual, so it is often referred to as a virtual classroom. Meanwhile, asynchronous means not at the same time. Students can choose different learning times with educators providing material so that students can access learning material anywhere and anytime. However, it is still adjusted to the learning contract. Students can carry out learning and complete it at any time according to a predetermined time span. Four dimensions were investigated in the design of asynchronous online discussion: flexibility of time, the flexibility of place, instruction/guidance, and topic (G.P.R et al., 2019).

Recently a composition of Learning Management System (LMS) and Content
Management System (CMS) has been utilized in eLearning. However, LCMS uses the electricity of CMS with the combination of LMS (Ninoriya et al., 2011). LMS provides teachers with opportunities to create and present learning materials, monitor student participation, and maintain student activities and progress in accordance with learning objectives. Riyadi (2010) explains that LMS is software used to create web-based online lecture materials and manage learning activities and their results. Meanwhile, LCMS is concerned with managing the content of the material stored in the material database repository. At the same time, the virtual environment means that students can communicate and share information with other students or instructors (trainers, teachers, or educators) and access all available resources.

One of the LMS that can be applied at the university level is Schoology. Schoology (www.schoology.com) is one in every of numerous styles of Social Learning Networks (SLN) that mixes numerous functions of the Learning Management System (LMS) and numerous social networking functions (Social Network), turning into an appealing and easyto-use mastering media, which have become referred to as Social Learning Networks (Hilyana \& Hakim, 2018). Schoology is a website-based application that combines elearning and social networking (Aminoto \& Pathoni, 2014). The features of Schoology are as follows: (1) Courses, courses menu allows us to create a new class, join an existing class, or browse through a predefined class list; (2) Groups, this feature functions like wall messages on Facebook where group members can also post wall messages. (3) Resources maintains and tracks documents, files, and pictures uploaded in class; (4) Recent Activity displays the latest news contained in the Schoology account. Users can post and update in the account and choose which pages to post; (5) Calendar, it shows calendar pages that have been previously posted in Recent Activity; (6) Messages, it functions to send messages or view messages between Schoology users; (7) People, it enables us to see a list of users in a class.

Schoology is one utility that may enhance motivation and assist college students in looking at more (Anggraeni \& Rachmijati, 
2021). Using e-learning with Schoology is also more profitable because the management is user-friendly. Especially with Schoology-based e-learning use and students can learn anytime and anywhere. With Schoology, students and teachers can interact socially because in Schoology feature has links to various social media. Teachers can also see student attendance and control the activities that students undertake during the use of Schoology (Supratman \& Purwaningtias, 2018). The advantages of Schoology are the availability of Attendance facilities that are used to check students' attendance and the Analytic facility to see all student activities on each course, assignment, discussion, and activity that we prepare for students. The management of the e-learning platform greatly influences the online learning process. The quality of learning is expected to be no different from offline learning because, on the one hand, online learning is more flexible so that students can manage time to learn independently. Blended learning can be supported using Schoology media (Linda et al., 2020).

An operational fine of studying may be interpreted because of the depth of systemic and synergistic linkages amongst teachers, students, studying climate, and studying media in generating foremost studying strategies and consequences according to curricular demands (Haryati \& Rochman, 2012). The quality of learning is an achievement level of the learning objectives by increasing knowledge and skills and developing student attitudes through the learning process. The quality of learning can measure the extent to which the level of achievement of the learning objectives itself.

Learning objectives that have been achieved will produce optimal learning outcomes from students. Quality can be interpreted as effectiveness. According to the Ministry of National Education in Prasetyo (2013: 13), signs of the fine of gaining knowledge encompass trainer-gaining knowledge of behavior, particularly capabilities wherein a trainer suggests popular traits of someone associated with information and capabilities might be manifested withinside the shape of action. Second, the behavior or activities of students. Activities are not handiest studying, analyzing books, taking notes, or taking note of the teacher's explanation.
Activities of students can be activities carried out other than the academic field. Third, the learning climate is a conducive classroom atmosphere and a comfortable learning atmosphere. Fourth, good knowledge of material, visible from its suitability with gaining knowledge of targets and competencies, must be taken. Fifth, learning media, the extent to which these media can create an active learning atmosphere, facilitate the interaction between students and educators, and among students, students, and learning materials. Sixth, a learning system that can demonstrate its quality.

Several preceding studies use Schoology e-getting to know media to enhance scholar-toknow outcomes (Sugiarto, 2017). The results of these studies experimentally showed that students could get an excellent average score at the posttest. Compared to the research conducted by Sugiarto, this study does not measure students' learning outcomes through the pretest and posttest. Instead, evaluating the quality of learning is based on LMS Schoology at the university level. Meanwhile, the research aims to compare vocational school students' cognitive learning outcomes and motivation levels using Schoology-based e-learning methods and Edmodo (Tigowati et al., 2017). The results showed that the cognitive learning outcomes of the Schoology-based e-learning method were better than Edmodo and the motivation of students with Schoology-based elearning was better than the class with the use of Edmodo-based e-learning. Therefore, the researcher decided to examine the LMS Schoology and its effectiveness from the point of view of the quality of learning at the university level. Therefore, because students have begun to be required to familiarize themselves with online learning, it is necessary to conduct research related to LMS used in learning because it still has to produce a minimum quality of learning that is the same as when learning offline.

\section{METHOD}

This has a look makes use of a qualitative method to recognize the phenomena skilled using studies subjects, including behavior, perceptions, and motivation. Descriptive methods are studies designed to supply a lowinference description of a phenomenon (Kahlke, 2014). In the educational scientific 
context, there were surveys on the everyday life of elementary pupils or the images of a young world delivered by the media (Bohnsack et al., 2010). The subject's technique is purposive sampling, which is based on specific objectives or considerations first (Hardani, 2020). The subjects in this study were 41, namely 2 (two) informants representing academics and 39 informants who were students. The students consist of 16 boys and 23 girls with the developmental age of early adulthood, which is 19-25 years old and is taking semester 4 in 2021. The selection of students used purposive sampling with the following criteria: (1) 19-25 years old as of January 2021; (2) Currently taking semester 4 in 2021; (3) Have never used LMS Schoology; (4) Have used other LMS such as Edmodo and Google Classroom. The data collection technique uses the method of literature study, observation, interviews, and documentation. The first data collection technique begins with an in-depth interview stage. The first data collection technique begins with the periodic in-depth interview stage from September to December 2020 (during the 2020/2021 odd semester lecture period). Indepth interviews are methods that allow interviewers to ask respondents in hopes of obtaining information about the phenomenon being studied (Rosaline, 2011). Researchers used the snowball sampling technique, which is sampling with a chain method that starts from 1 informant from academics then finds another informant recommended by the previous informant with predetermined conditions. Researchers also used purposive sample interviews that are conversations conducted with a purpose. So researchers will use snowball sampling to find other recommended informants so that the network researchers want to look for can be well mapped and structured (Edmonds, 2019). Interviews built by researchers are conducted with one goal: to map the advantages and disadvantages in the learning process and interpret the process that occurs in producing quality learning. Researchers also used field notes during observation in checklists to determine students' responses when carrying out online learning.
The object of research in all aspects of the quality of learning is produced through the application of Schoology-based e-learning. The facts evaluation technique uses ranges beginning from facts collection, facts reduction, facts presentation, and concluding. Test the validity of the facts through credibility and look at the use of triangulation of reassets and triangulation of techniques. Source triangulation compares data obtained through interviews with data obtained by direct observation or from related documents. The documents analyzed are the results of written discussions in Schoology, written interactions in Schoology updates feature, presence in Schoology, and test results conducted in Schoology. Observation guidelines in this study include facilities, facilities, and infrastructure used: geographical location, attitudes and behaviors during lectures, and the liveliness of learners. While the interview guidelines in this study are impressions during lectures, obstacles faced, benefits felt by learners. Time triangulation is completed via checking with interviews, observations, or different strategies in distinct instances or situations, particularly at some point of look at hours and out of doors look at hours.

\section{RESULT}

The advantages of using Schoology are that users can choose to access via the website or an application that can be downloaded for free in the Play Store, questions and answers sessions can be done at any time, students feel free to argue because of the lack of distractions such as the temptation of friends, crowded class, and embarrassment to speak in public. Furthermore, Schoology also supports the gogreen movement because there is no need for hard files of tasks, easy use, easy tools to understand, easy task control, and attendance. While the shortcomings in using Schoology include an increased budget for data usage, no feature to check plagiarism, less stable when using the application in a place where the signal is not good. Figure 1 is an example when the signal is not good, so students have to repeat 7 times. 


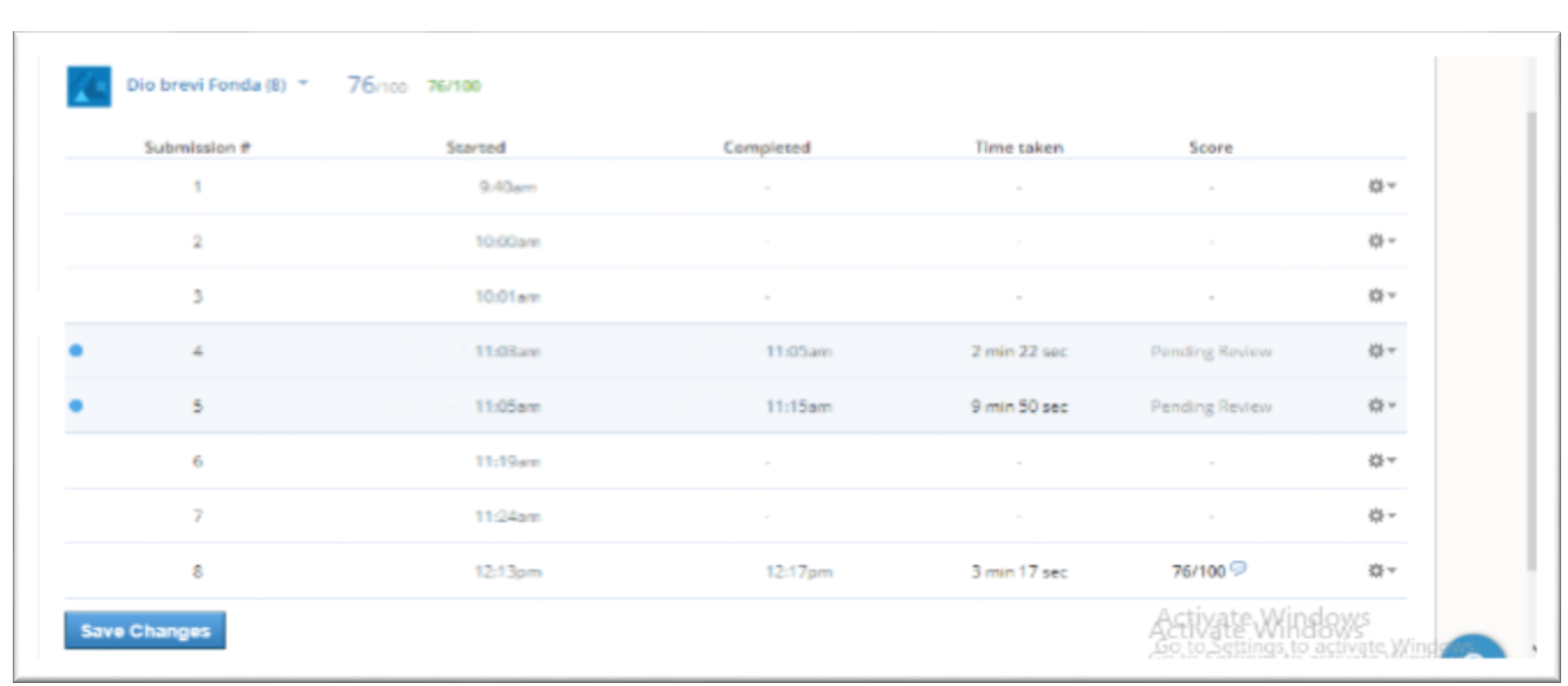

Figure 1. Repeat Submission

Furthermore, qualitative data through observations about teaching and learning situations. Some of the activities carried out by educators and students at Schoology include discussions, questions and answers, quizzes, presentation of material, and submission of assignments. In contrast to offline learning, with Schoology, all students can efficiently provide opinions in discussions and questions and answers. However, it should be noted carefully if students cannot receive the material properly through Schoology. The results of the observations found several things; namely, students found it difficult to digest material that ran faster when compared to offline learning, students did not focus on using Schoology because they opened other sites at the same time, or educators were less creative in processing material so that students feel bored.

\section{DISCUSSION}

E-learning can carry a brand new ecosystem in numerous mastering developments (Sukanto, 2020). Regarding LMS Schoology, Schoology can be accessed through the website, namely app.schoology.com, and through the smartphone application, which can be downloaded on the Play Store for free. Schoology has features that are quite complete. The materials feature consists of adding assignments, testing, adding assessment, adding a file, adding discussion, adding a page, adding media album, adding package, importing or from resources, a finding in resources. All materials in the materials feature can be set the date when they will be published or hidden. Schoology is one of the LMS that is deemed suitable to support learning activities (Indrawati et al., 2021).

For example, when starting a quiz, teachers can hide previously published material without deleting it. Figure 2 is hidden material capture. Several types of quizzes exist, namely multiple-choice, true-false, matchmaking, and short entries. In addition, if the educator has prepared a special template for questions, it can be done by importing questions. All questions containing pictures, symbols, and equations can be written in Schoology because this LMS is equipped with Symbol, Equation, and Latex. The updates feature can be used to deliver all information related to learning, such as schedule changes, notification of new material, question and answer assignments.

With the updates feature, if students do questions and answers related to assignments or material, this surely can be useful for other students, compared to asking through private networks. Schoology also helps educators in opening up vast communication opportunities to students in discussion activities. This can be done by opening the add discussion feature. Through this feature, educators can assess the discussions conducted by students, see the level of activity of students during the discussion process, and make observations related to learning objectives or other things. Figure 3 is a screenshot of the midterm exam in the form of an essay through Schoology. 


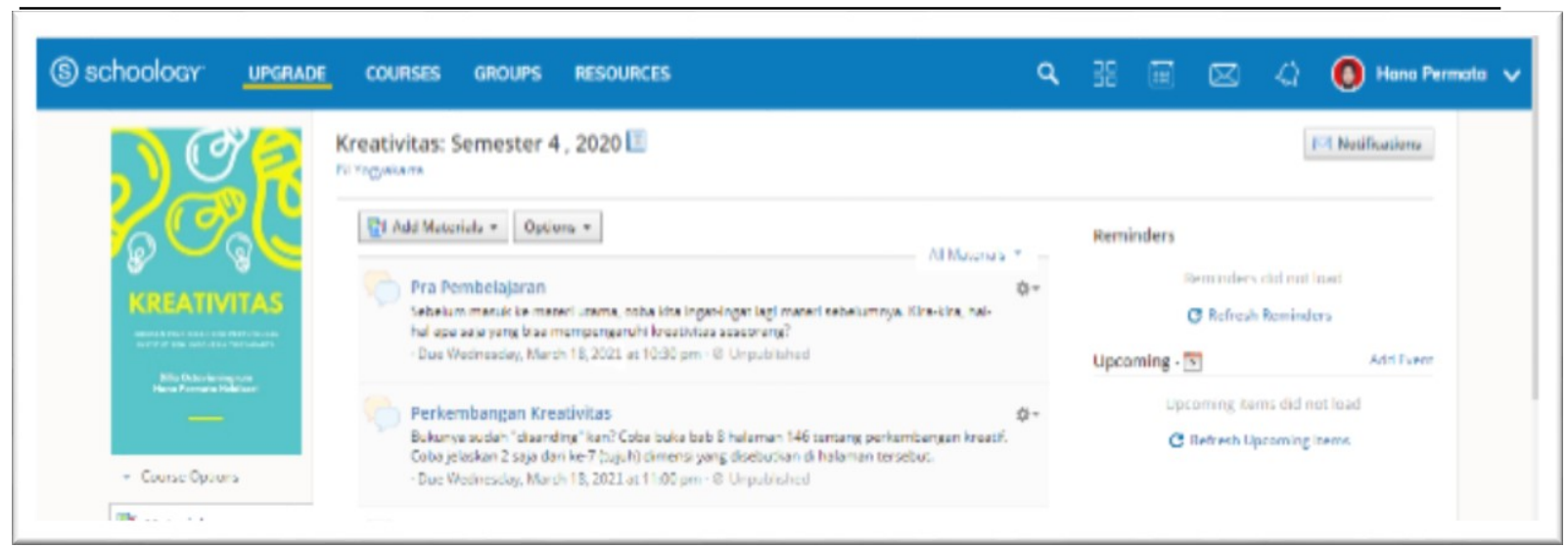

Figure 2. Hidden Material Capture

The advantage of the Schoology-based elearning method is that it increases students' motivation in learning. Students are more enthusiastic because it is easy to access. Schoology can be called a "pocketbook" because Schoology can now be used on mobile phones so that it can be carried anywhere and used anywhere (Sitinjak, 2020). The existing tools are easy to understand according to their function and are not complicated. In addition, students have an interest in using new learning media that is different from offline learning. Students are more active in learning and are serious about doing every task. This is triggered by the existence of a deadline that is read by the system. Schoology-based e-learning fosters the attitude of students to be more independent in learning. In addition, Schoology-based elearning also makes learning more exciting. It can increase knowledge because of the various resources provided. Schoology has also proven effective in improving critical thinking skills with a problem-based learning approach (Febrianto et al., 2021). So as the application of science virtual learning-based Schoology can improve students' critical thinking skills in junior high school (Budhiman et al., 2021).

Schoology-based e-learning is carried out to improve the quality of learning (Aminoto \& Pathoni, 2014). From the indicators of learning quality formulated by the Ministry of National Education, the first is the learning behavior of educators. Learning behavior, namely skills in teaching related to knowledge and skills manifested in the form of action. Online and offline communication is different. No intonation can be heard. There is no expression when uttering words. The beheading can be interpreted differently between students. Therefore, educators should be able to convey material by minimizing misperceptions. In this study, it is infrequent to find misperceptions. There may only be a selection of words that are less familiar to students. However, it is immediately confirmed by these students so that there is no prolonged confusion. This shows that communicating through writing is becoming more honed, both for students and educators. Schoology contributed to the writing skill improvement, at some point of the mixing of things just like the motivation, the notion of appealing sports and the improvement of obligations in the lecture room and outdoor it (Rodríguez Tamayo \& Vargas Hernández, 2020).

Second, the behavior or activities of students. In this case, the activity is not limited to academic activities. To learn about this, students are given the task of making short stories about activities carried out during the physical distancing period. From the analysis of these documents, it can be seen that students' creativity in their activities is increasing in these very different circumstances. Entrepreneurial activities, continuing to make art with all the limitations of the circumstances, can still be carried out, for example, helping to spray the environment with disinfectants. In addition, students indirectly improve their linguistic verbal intelligence in making short stories. They are more active because they have an obligation to argue in discussion forums. Figure 4 is the implementation of discussions through Schoology. 


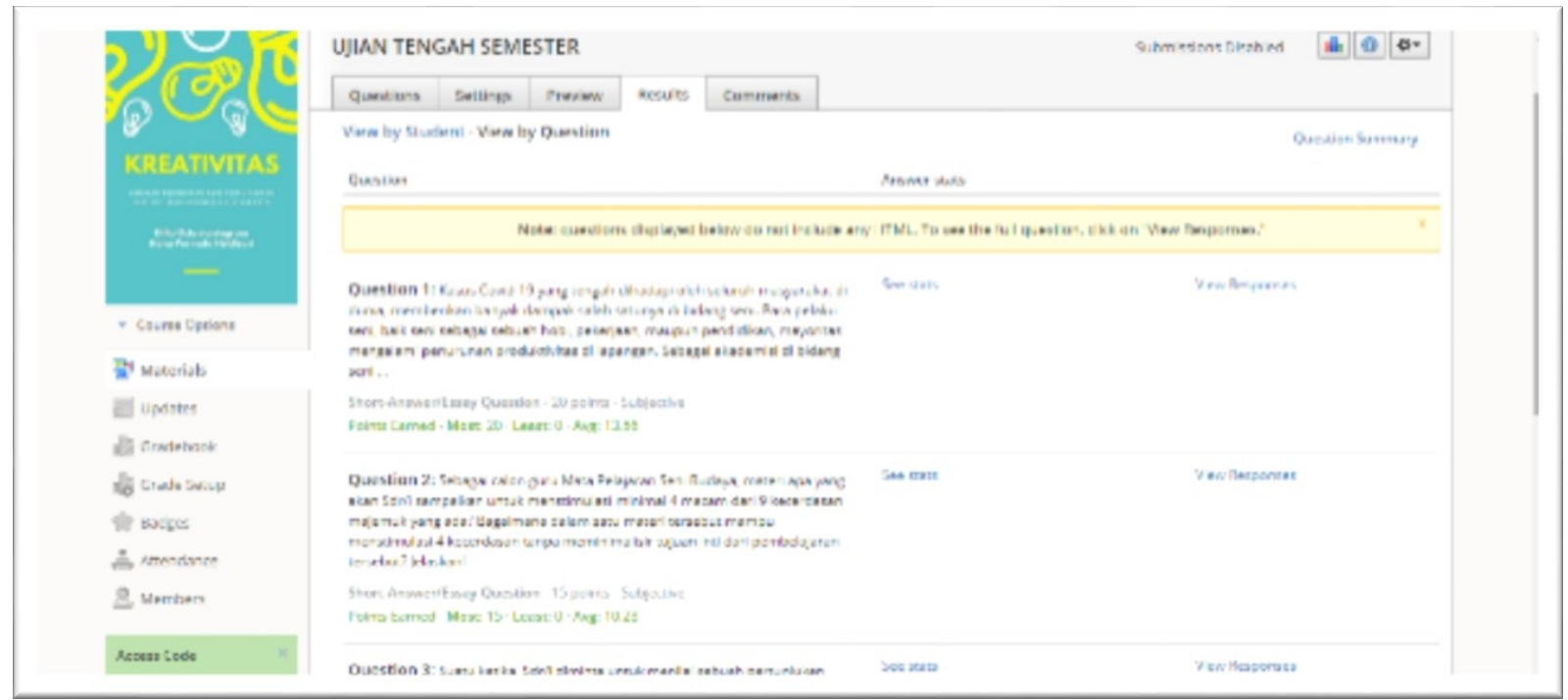

Figure 3 Essay through Schoology

Perkembangan Kreativitas

$\theta$

Write a comment

Moh Yudha Mangemba

-proses sosial/emasi karena proses sosial juga mencakup hualitas dan pengalaman personal yang cenderung menjadi karaizer orang yang dikategorikan

cebagai kreast. Sehingga proses sosial juga penting dalam pengembangan kreativitas karena in mencakup lingliungan yarg akan dis bangun. keluarga

karena disisin merupakan aspek yang terpensing keluarga terveama orang tua berperan sebagai mosivator dari anak, jha keluarga tidak memotivasi arau cenderung menjowhican makan perkembangan kreativitas mungkin bisa tertiambari

Show less

Like · Reply

L Hide An 4 Replies

8

Dilla Octavia

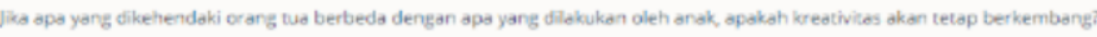

Like - Reply

Figure 4. Discussions Through Schoology

The third is the learning climate: a conducive classroom and a comfortable learning atmosphere (Muhid \& Ferdiyanto, 2020). One of the advantages of e-learning is that students can carry out learning anywhere. Each individual creates a class atmosphere independently. However, educators still play a role in determining the right learning strategy not to feel bored quickly. Fourth, quality learning material, seen from its suitability with learning objectives and competencies, must be taken. Learning materials are more focused because of the minimalism of distractions compared to face-to-face. Students are more focused on listening to the material.

Fifth, the extent to which the learning media can create an active learning atmosphere facilitates interaction between students and educators, among students, students, and learning materials. The selection of media types is quite diverse and can be tailored to users. The attendance feature shows whether the student is on time or late in collecting assignments. Therefore, Schoology is beneficial for students in making target values for themselves.

Sixth, a learning system that can demonstrate its quality. Based on observations 
and interviews conducted, Schoology can motivate students to have target values to be more serious in doing their assignments. The material presented has been well presented so that students are excited to learn it. In addition, students become more disciplined in attendance because from the needs. For example, the type of audio can be selected when only needed to listen to a conversation or present a case. Audiovisuals can be selected when an image, sound, and explanation are needed on the material. The assignment feature can arrange teaching materials, work orders, questions, and deadlines for collection. Teacher creativity in preparing the material is the primary key to learning. It impacts the level of pleasure and satisfaction of students in following the learning process.

\section{CONCLUSION}

Schoology is a social media platform for educators and students that shares ideas, files, agendas of activities, and assignments to create interaction between educators and students. Therefore, Schoology can be an alternative to an e-learning based teaching process, with various exciting and easy-to-use features.

The proper use of e-learning can produce quality learning, including 1) the ability to communicate through writing, both for students and educators; 2) students become more active because they have an obligation to argue in discussion forums; 3 ) each individual is able to create a class atmosphere independently, but it does not rule out the educator's role to determine the right learning strategy so that students do not get bored quickly; 4) the learning material is more focused because of the minimalism of distractions compared to face to face. In addition, the use of Schoology-based e-learning motivates students to have target values . They are more severe in doing assignments and more disciplined in both attendance and assignment collection.

Suggestions for using LMS Schoology should further pay attention to several things. Educators should further explore the features of the LMS Schoology in order to optimize the use of the LMS. Meanwhile, students should be given guidance on the use of LMS Schoology to maximize LMS use in the learning process.

\section{REFERENCES}

Aminoto, T., \& Pathoni, H. (2014). Penerapan Media E-Learning Berbasis Schoology Untuk Meningkatkan Aktivitas dan Hasil Belajar Materi Usaha dan Energi Di Kelas XI SMA N 10 Kota Jambi Tugiyo. Sainsmatika, 28(1), 13-29.

Anggraeni, A., \& Rachmijati, C. (2021). The Use Of Schoology As An Alternative Of Learning Applications in The Covid-19 Pandemic Period To Improve Students Writing Ability. PrimaryEdu - Journal of Primary Education, 5(1), 119. https://doi.org/10.22460/pej.v5i1.2138

Bohnsack, R., Pfaff, N., \& Weller, W. (2010). Qualitative Analysis and Documentary Method: In International Educational Research. In Barbara Budrich Publishers Opladen \& Farmington Hills. https://doi.org/10.3224/86649236

Budhiman, A., Ellianawati, E., \& Wahyuni, S. (2021). Implementation of Science Virtual Class Based Schoology in Improving Students' Critical Thinking Skill. Journal of Innovative Science Education, 10(2), 209-215.

Choirudin, C. (2017). Efektivitas Pembelajaran Berbasis Schoology. NUMERICAL: Jurnal Matematika Dan Pendidikan Matematika, l(2), 52-62. https://doi.org/10.25217/numerical.v1i2.131

Edmonds, W. (2019). Snowballing ... \#Prayforme: A Qualitative Study Using Snowball Sampling. In Snowballing ... \#Prayforme: A Qualitative Study Using Snowball Sampling. https://doi.org/10.4135/9781526491039

Febrianto, T., Ngabekti, S., \& Saptono, S. (2021). The effectiveness of schoology-assisted PBLSTEM to improve critical thinking ability of Junior High School Students. Journal of Innovative Science Education, 10(908), 222229.

https://journal.unnes.ac.id/sju/index.php/jise/a rticle/view/42993

G.P.R, D., L.D.S., A., \& K.S., P. (2019). Students Perception on The Design Of Asynchronous Online Discussion Using Schoology In English Language Education Ganesha University of Education. International Journal of Language and Literature, 3(1), 1. https://doi.org/10.23887/ijll.v3i1.20597

Hardani. (2020). Metode Penelitian Kualitatif \& Kuantitatif. In CV. Pustaka Ilmu Editor.

Haryati, T., \& Rochman, N. (2012). Peningkatan 
Heldisari-Schoology-Based E-Learning.... 215

Kualitas Pembelajaran Pendidikan

Kewarganegaraan Melalui Praktik Belajar

Kewarganegaraan (Project Citizen). Jurnal Ilmiah Civis.

Hilyana, F. S., \& Hakim, M. M. (2018). Integrating character education on physics courses with schoology-based e-learning. Journal of Information Technology Education: Research, 17, 577-593. https://doi.org/10.28945/4164

Indrawati, F. A., Wadono, \& Junaedi, I. (2021). Mathematics Literacy Ability in Terms Of Self Efficacy in Cooperative Learning Type of Group Investigation Model With HumanismApproachAssisted by Schoology. Unnes Journal of Mathematics Education Research, 11(1), 83-93. https://journal.unnes.ac.id/sju/index.php/ujme r/article/view/39619

Kahlke, R. M. (2014). Generic qualitative approaches: Pitfalls and benefits of methodological mixology. International Journal of Qualitative Methods, 13(1), 37-52. https://doi.org/10.1177/160940691401300119

Linda, R., Anggraini, C., \& Abdullah. (2020). The Development of Schoology as Media to Supporting Blended Learning on Stoichiometry Topic. Journal of Physics: Conference Series, 1655(1). https://doi.org/10.1088/17426596/1655/1/012063

Muhid, A., \& Ferdiyanto, F. (2020). Stres akademik pada siswa: Menguji peranan iklim kelas dan school well-being. Persona:Jurnal Psikologi Indonesia, 9(1), 140-156. https://doi.org/10.30996/persona.v9i1.3523

Ninoriya, S., Chawan, P. ., \& Meshram, B. . (2011). CMS, LMS and LCMS For eLearning. International Journal of Computer Science Issues, 8(2), 644-647.

Rahmadoni, J., Arifnur, A. A., \& Wahyuni, U. M. (2020). Penerapan Schoology Sebagai Learning Management System Bagi Guru SMA N 1 Sutera. Jurnal Hilirisasi IPTEKS, $3(2)$, 129-137. https://doi.org/10.25077/jhi.v3i2.418

Rodríguez Tamayo, I. Y., \& Vargas Hernández, L. J.
(2020). Schoology: una herramienta para el desarrollo de la habilidad escrita en inglés. Colombian Applied Linguistics Journal, 22(1), 13-28.

https://doi.org/10.14483/22487085.14348

Rosaline, B. (2011). Introducing Qualitative Research. In Introducing Qualitative Research. https://doi.org/10.4135/9780857029034

Sitinjak, A. A. (2020). The Effect of Learning Method Schoology Applications and Learning Style on Student Learning Outcomes. International Journal for Innovation Education and Research, 8(6), 113-119. https://doi.org/10.31686/ijier.vol8.iss6.2380

Sugiarto, D. M. P. (2017). Pengembangan ELearning Berbasis Schoology untuk Meningkatkan Hasil Belajar Siswa pada Mata Pelajaran Jaringan Dasar Kelas X TKJ. It-Edu, 2(01), 1 .

Sukanto, D. (2020). Pembelajaran Jarak Jauh Dengan Media E-Learning Sebagai Solusi Pembelajaran Pada Masa Pandemi Corona Virus Disease 2019 (Covid-19). Syntax Idea, 2(11).

Supratman, E., \& Purwaningtias, F. (2018). Pengembangan Media Pembelajaran ELearning Berbasis Schoology. Jurnal Informatika: Jurnal Pengembangan IT, 3(3), 310-315. https://doi.org/10.30591/jpit.v3i3.958

Tambunan, L., Rusdi, R., \& Miarsyah, M. (2018). Efectiveness of Problem Based Learning Models by Using E-Learning and Learning Motivation Toward Students Learning Outcomes on Subject Circullation Systems. Indonesian Journal of Science and Education, 2(1),

96. https://doi.org/10.31002/ijose.v2i1.598

Tigowati, T., Efendi, A., \& Budiyanto, C. W. (2017). E-learning Berbasis Schoology Dan Edmodo: Ditinjau Dari Motivasi dan Hasil Belajar Siswa SMK. Elinvo (Electronics, Informatics, and Vocational Education), 2(1), 49-58. https://doi.org/10.21831/elinvo.v2i1.16416 